\title{
Development of an Immunoassay for the Detection of Amyloid Beta 1-42 and Its Application in Urine Samples
}

\author{
Anurak Wongta $\mathbb{D}^{1,2}$ Surat Hongsibsong $\mathbb{D}^{1,2,3}$ Somporn Chantara ${ }^{1}{ }^{4}{ }^{4}$ \\ Mookda Pattarawarapan $\mathbb{D D}^{5}$ Ratana Sapbamrer $\mathbb{D D}^{6},{ }^{6}$ Korawan Sringarm $\mathbb{D}^{3,7}$ \\ Zhen-Lin Xu $\mathbb{D}^{8},{ }^{8}$ and Hong Wang ${ }^{8}$ \\ ${ }^{1}$ Environmental Science Ph.D. Program, Faculty of Science, Chiang Mai University, Chiang Mai 50200, Thailand \\ ${ }^{2}$ School of Health Science Research, Research Institute for Health Science, Chiang Mai University, Chiang Mai 50200, Thailand \\ ${ }^{3}$ Cluster of Research and Development of Pharmaceutical and Natural Products Innovation for Human or Animal, \\ Chiang Mai University, Chiang Mai 50200, Thailand \\ ${ }^{4}$ Environmental Chemistry Research Laboratory, Department of Chemistry, Faculty of Science, Chiang Mai University, \\ Chiang Mai 50200, Thailand \\ ${ }^{5}$ Department of Chemistry and Center of Excellence for Innovation in Chemistry, Faculty of Science, Chiang Mai University, \\ Chiang Mai 50200, Thailand \\ ${ }^{6}$ Department of Community Medicine, Faculty of Medicine, Chiang Mai University, Chiang Mai 50200, Thailand \\ ${ }^{7}$ Department of Animal and Aquatic Science, Faculty of Agriculture, Chiang Mai University, Chiang Mai 50200, Thailand \\ ${ }^{8}$ Guangdong Provincial Key Laboratory of Food Quality and Safety, College of Food Science, South China Agricultural University, \\ Guangzhou 510642, China
}

Correspondence should be addressed to Surat Hongsibsong; surat.hongsibsong@cmu.ac.th

Received 9 September 2020; Revised 8 December 2020; Accepted 11 December 2020; Published 28 December 2020

Academic Editor: Xiao Feng Yang

Copyright ( 2020 Anurak Wongta et al. This is an open access article distributed under the Creative Commons Attribution License, which permits unrestricted use, distribution, and reproduction in any medium, provided the original work is properly cited.

Amyloid beta peptides (A $\beta 1-42)$ have been found to be associated with the cause of Alzheimer's disease (AD) and dementia. Currently, methods for detecting A $\beta 1-42$ are complicated and expensive. The present study is aimed at developing an indirect competitive enzyme-linked immunosorbent assay (ic-ELISA) to detect A $\beta 1-42$ by using a polyclonal antibody from alpaca, an application used in urine samples. The serum was collected from the alpaca after immunizing it with A $\beta 1-42$ at $500 \mu \mathrm{g} / \mathrm{injection}$ 5 times. The ic-ELISA was developed and showed a half-maximal inhibitory concentration $\left(\mathrm{IC}_{50}\right)$ of $103.20 \mathrm{ng} / \mathrm{ml}$. The limit of detection (LOD) was $0.39 \mathrm{ng} / 100 \mu \mathrm{l}$. The cross-reactivity was tested with $\mathrm{A} \beta 1-40$ and 8 synthesized peptides that had sequence similarities to parts of $\mathrm{A} \beta 1-42$. The cross-reactivity of $\mathrm{A} \beta 1-40$ and peptide 1 (DAEFRHDSGYE) was $55 \%$ and $69.4 \%$, respectively. The ic-ELISA was applied to analyze $A \beta 1-42$ in the urine and precipitated protein urine samples. This method can be used for detecting a normal level of total soluble $\mathrm{A} \beta$ (approximately $1 \mathrm{ng}$ in $5 \mathrm{mg}$ of precipitated urine protein) and can be used for detecting the early stages of $\mathrm{AD}$. It is considered to be an easy and inexpensive method for monitoring and diagnosing $\mathrm{AD}$.

\section{Introduction}

Alzheimer's disease (AD) is an age-related chronic degenerative disease that damages the nervous system. It is mostly found in the elderly as a progressive neurodegenerative disease that predominantly affects cognitive functions [1]. The increasing number of $\mathrm{AD}$ patients is becoming an issue of serious concern due to the concomitant rise in medical and social costs. $\mathrm{AD}$ can be caused by several reasons, such as genetic causes, aging, malnutrition, immune system dysfunction, infectious agents, severe brain damage, congenital diseases (i.e., hypertension and diabetes), and the environment (i.e., exposure to pesticides or aluminum) $[2,3]$.

Amyloid beta peptides $(\mathrm{A} \beta)$ are neurotrophic and neurotoxic proteins that are used as a biomarker for detecting $\mathrm{AD}$. Extracellular $\mathrm{A} \beta$ can lead to synapse loss and oxidative stress. 
Intracellular $\mathrm{A} \beta$ can increase the production of free radical species (ROS), causing increased levels of neurotoxicity and the death of neurons $[4,5] . \mathrm{A} \beta$ is formed after sequential cleavage of the amyloid precursor protein (APP) by $\beta$-secretase, which removes the soluble $\operatorname{APP} \beta(\operatorname{sAPP} \beta)$ and leaves a 99 amino acid C-terminal APP fragment (C99) in the cell membrane. Then, C99 is serial cleaved by $\gamma$-secretase at the $\varepsilon^{-}, \zeta_{-}$, and $\gamma$-sites in the transmembrane domain (TMD), which releases the APP intracellular domain (AICD) into the cytosol and the $37-43$ amino acid $A \beta$ species into the extracellular space [6]. A $\beta$ molecules can aggregate to form flexible soluble oligomers that may exist in several forms [7]. $\mathrm{A} \beta$ is the major constituent of the fibrils deposited into senile plaques and cerebral blood vessels of patients with $\mathrm{AD}$. For $\mathrm{A} \beta$ levels under normal conditions, the daily excretion of intact soluble amyloid beta in the urine represents less than $1 \%$ of the circulating pool [8].

Several genetic, cell biology, biochemical, and animal studies support the concept that $\mathrm{A} \beta$ plays a central role in the development of $\mathrm{AD}$ pathology $[9,10]$. The most common isoforms are $A \beta 1-40$ and $A \beta 1-42$ [11]. $A \beta 1-42$ and $A \beta 1-43$ are the major constituents of senile plaques and neurofibrillary tangles that occur in the hippocampus, neocortex, and amygdala of patients with $\mathrm{AD}$ [12]. A $\beta 1-42$ is a good marker for the early stages of $\mathrm{AD}$ and is often detectable in several biological samples such as CSF, saliva, and urine in normal stages before the patient shows symptoms of $\mathrm{AD}$, suggesting it is involved in the cause of $\mathrm{AD}$ [13-15].

Brain imaging techniques, which are crucial in the assessment of patients with $\mathrm{AD}$, include fluoro-D-glucose integrated with positron emission tomography (FDG-PET) and amyloid positron emission tomography (amyloid PET) imaging $[16,17]$. However, there are still many limitations of these methods, including cost, potential complications, the need for a specialist, and the requirement for high-performance equipment. While these conventional methods for identifying $\mathrm{AD}$ by detecting $\mathrm{A} \beta 1-42$ are still required and useful, they cannot detect the early stages of $\mathrm{AD}$.

The immunoassay is a simple, economical technique with high sensitivity and specificity $[18,19]$ that can be developed and applied to biological samples. In the present day, immunoassays for human $\mathrm{A} \beta$ have been developed and can be purchased from pharmaceutical companies throughout the world. The most commercial enzyme-linked immunosorbent assay (ELISA) test kits are developed based on sandwichELISA, which requires two antibodies to detect the target antigen. They are used for serum, plasma, tissue homogenates, and cerebrospinal fluid (CSF). The sensitivity of commercial kits is a LOD between 4.73 and $1,000 \mathrm{pg} / \mathrm{ml}$ and a detection range between 7.8 and $480,000 \mathrm{pg} / \mathrm{ml}$ for all $\mathrm{A} \beta$. $\mathrm{A} \beta 1-42$ can be present at a lower concentration, where the LOD is between 4.73 and $9.38 \mathrm{pg} / \mathrm{ml}$. Conventional antibodies such as polyclonal antibodies (pAb) and monoclonal antibodies $(\mathrm{mAb})$ from rodents are used in the test kits. The price of one test kit is in the range of 395-875 dollars for 96 tests [20], which is far too expensive to be widely used.

This study was conducted to develop ELISA for detecting $\mathrm{A} \beta 1-42$ in urine samples in which $\mathrm{A} \beta$ is found as a normal component, and the monomeric $\mathrm{A} \beta$ level is related to the clinical dementia rating score (CDR) [21].

\section{Materials and Methods}

2.1. Preparation of the Antibody. A single alpaca was raised at Nanchang (Jiangxi Province, People's Republic of China) and immunized subcutaneously 5 times at 2 -week intervals with a $500 \mu \mathrm{g} /$ injection of $\mathrm{A} \beta 1-42$ to produce antibodies against $A \beta 1-42$. The immunogen was prepared with $A \beta 1$ 42, which was purchased from Thermo Fisher (USA), dissolved in phosphate-buffered saline (PBS) pH 7.2, and gently mixed with an equal volume of Freund's Complete Adjuvant (Sigma-Aldrich, USA) to make an emulsion for the first immunization and Freund's Incomplete Adjuvant (SigmaAldrich, USA) to make an emulsion for the $2^{\text {nd }}, 3^{\text {rd }}, 4^{\text {th }}$, and $5^{\text {th }}$ immunization. The blood was collected from the jugular vein of the alpaca before the $4^{\text {th }}$ and $5^{\text {th }}$ injection and 1 week after the last immunization. The $5^{\text {th }}$ serum was used to develop the method in this study. The protocol of the experiment was approved by the animal ethical committee of South China Agricultural University, Guangdong, Guangzhou, China, and the study has been conducted in accordance with the guidelines for the animal screening of antiserum.

2.2. Indirect ELISA for the Titration of the Alpaca Antiserum. An indirect ELISA was used to determine the optimal dilution factor of the antibodies that were later used in icELISA procedure $[22,23]$. Standard A $\beta 1-42$ was serially diluted into coating buffer (carbonate buffer, $\mathrm{pH}$ 9.6), producing 11 concentrations of $\mathrm{A} \beta 1-42$, and coated on Maxisorp microwell plates (Thermo Fisher Scientific, Denmark) at $4^{\circ} \mathrm{C}$ for 16 hours overnight. After incubation, the plate was washed 4 times with $400 \mu \mathrm{l} /$ well PBST (PBS with $0.05 \%$ Tween) by a microplate washer (Thermo Fisher Scientific, Finland) and dried by patting with paper towels. After washing, the plate was blocked with $200 \mu \mathrm{l} /$ well of $1 \%$ skim milk in PBS as a blocking solution and incubated for 1 hour at $25^{\circ} \mathrm{C}$. Then, the blocking solution was discarded, and the plate was dried by patting with paper towels. Alpaca antiserum, which was prepared with 8 dilutions from $1: 1,000$ to $1: 32,000$, was added to the wells and incubated for 1 hour at $25^{\circ} \mathrm{C}$. Then, the plate was washed as in the previous washing procedure. In the next step, $100 \mu \mathrm{l}$ of goat anti-llama IgG labeled with horseradish peroxidase (1:5,000 in PBST) (Abcam, USA) was added to each well and incubated for 1 hour at $25^{\circ} \mathrm{C}$. Then, the washing procedure was repeated. For determination, $100 \mu \mathrm{l}$ of TMB substrate $(12.5 \mathrm{ml}$ citrate buffer $\mathrm{pH} 4$, $200 \mu \mathrm{l}$ stock $\mathrm{TMB}$, and $50 \mu \mathrm{l}$ of $1 \% \mathrm{H}_{2} \mathrm{O}_{2}$ ) was added and rested in the dark at $25^{\circ} \mathrm{C}$ for $10 \mathrm{~min}$. The reaction was stopped with $2 \mathrm{M} \mathrm{H}_{2} \mathrm{SO}_{4}$. The optical density (OD) was measured at $450 \mathrm{~nm}$ in a multiscan spectrophotometer (Tecan, Austria) to evaluate the optimal dilution of the alpaca serum and the concentration of coating [24].

2.3. Indirect Competitive ELISA for Quantification of A $\beta 1-42$. The ic-ELISA assay was performed with alpaca antiserum (1:1,000 in PBST), and the competition between the free 
standard $A \beta 1-42$ and the coated antigen $(A \beta 1-42)$ was observed in order to determine the concentration of the free standard. The microwell plate was coated at $4^{\circ} \mathrm{C}$ for 16 hours overnight with $100 \mu \mathrm{l} /$ well of 3 concentrations of coating antigen (A $\beta-42,2-4 \mu \mathrm{g} / \mathrm{ml}$ in coating buffer). The plate was then washed and blocked as described above. An equal volume of standard $\mathrm{A} \beta-42$ was added to the alpaca antiserum in a u-shaped plate at $25^{\circ} \mathrm{C}$ for 1 hour. After the blocking solution was discarded and dried, the mixture of standard A $\beta 1-42$ and alpaca antiserum was added in triplicate to the wells of each coating antigen. After the plate was incubated for 1 hour at $25^{\circ} \mathrm{C}$ and washed, anti-llama IgG labeled with horseradish peroxidase $(1: 5,000$ in PBST) and TMB substrate were added following the ELISA protocol, as described above.

The specificity and sensitivity of this method were measured with alpaca antiserum (1:1,000 in PBST), and the competition between the free standard $\mathrm{A} \beta 1-42$ with the coated antigen (A $\beta 1-42)$ was observed. The microwell plate was coated at $4^{\circ} \mathrm{C}$ for 16 hours overnight with $100 \mu \mathrm{l} /$ well of $2 \mu \mathrm{g} / \mathrm{ml} \mathrm{A} \beta 1-42$ in coating buffer. Twelve concentrations of competitive $\mathrm{A} \beta 1-42$ were prepared $(0-4,000 \mathrm{ng} / \mathrm{ml}$, twofold dilution), and ic-ELISA was performed with $1: 1,000(\mathrm{v} / \mathrm{v})$ dilution of alpaca antiserum, as described above.

The calibration curve was obtained and calculated as $\mathrm{IC}_{50}$ . The limit of detection (LOD) was calculated by using the formula [25] as follows:

$$
\mathrm{LOD}=B_{0}-3 \mathrm{SD} \text {, }
$$

where $B_{0}$ is the optical density (OD) of blank (no A $\beta 1-42$ ) and $\mathrm{SD}$ is the standard deviation of $B_{0}$.

2.4. Assessment of the Cross-Reactivity of A $\beta 1-42$ ic-ELISA. Standard $A \beta 1-40, A \beta 1-42$, and 8 synthesized $A \beta$ peptides (A $\beta 1-8, \mathrm{~A} \beta 7-15, \mathrm{~A} \beta 14-21, \mathrm{~A} \beta 20-27, \mathrm{~A} \beta 26-33, \mathrm{~A} \beta 32-39$, $\mathrm{A} \beta 35-42$, and $\mathrm{A} \beta 36-43)$ were tested in the ic-ELISA assay as described above. Calibration curves were obtained. The cross-reactivity (CR) values were calculated by using the formula [26] as follows:

$$
\begin{aligned}
& \text { Cross-reactivity rate }(\%) \\
& =\frac{\mathrm{IC}_{50} \text { of } \mathrm{A} \beta 1-42}{\left(\mathrm{IC}_{50} \text { of the structural-related protein }\right) \times 100},
\end{aligned}
$$

where $\mathrm{IC}_{50}$ is the half-maximal inhibitory concentration.

2.5. Preparation of the Urine Protein. A pool of urine was prepared from 10 healthy donors (5 male and 5 female) and used in this study. Due to the small amount of $A \beta 1-42$ in urine, the concentration of the urine proteins was increased by a precipitation technique. Urine protein was prepared by the salting out technique, which is the most common method used to precipitate proteins. Ammonium sulfate $\left(\left(\mathrm{NH}_{4}\right)_{2} \mathrm{SO}_{4}\right)$ was used to compress the solvation layer and increase the protein-protein interactions. The increasing salt concentration caused the protein to separate and fall to the bottom of the sample solution by aggregation and precipitation activities [27]. The precipitation was performed with
TABLE 1: Results of the ELISA checker-board titration test of the binding of 6 concentrations of $A \beta 1-42$ and 6 serially diluted antiserums by the indirect ELISA method.

\begin{tabular}{lcccccc}
\hline \multirow{2}{*}{ Antiserum $(1: \mathrm{X})$} & \multicolumn{6}{c}{ CD at $450 \mathrm{~nm}$} \\
& 4000 & 2000 & 1000 & 500 & 250 & 125 \\
\hline 1,000 & 1.053 & 0.938 & 0.852 & 0.74 & 0.644 & 0.525 \\
2,000 & 0.929 & 0.799 & 0.686 & 0.56 & 0.443 & 0.368 \\
4,000 & 0.821 & 0.622 & 0.475 & 0.379 & 0.272 & 0.217 \\
8,000 & 0.659 & 0.441 & 0.342 & 0.235 & 0.178 & 0.146 \\
16,000 & 0.456 & 0.278 & 0.203 & 0.149 & 0.113 & 0.099 \\
32,000 & 0.293 & 0.171 & 0.13 & 0.098 & 0.081 & 0.073 \\
\hline
\end{tabular}

$31.77 \mathrm{~g}$ of ammonium sulfate added to $100 \mathrm{ml}$ urine (to reach $50 \%$ saturation) and well-mixed by a magnetic stirrer for 1 hour on ice. Then, the mixture was centrifuged $4,000 \mathrm{rpm}$ for 1 hour at $4^{\circ} \mathrm{C}$. The supernatant was discarded; then, the protein pellet was resuspended in $1 \mathrm{ml}$ PBS buffer $(\mathrm{pH} 7.2)$ and kept at $4^{\circ} \mathrm{C}$.

2.6. Assessment of the Matrix Effect on Aß1-42 ic-ELISA Calibration Graph. The effects of urine and precipitated urine protein on the performance of the ic-ELISA were assessed. Twelve dilutions of each urine sample $(1: 1-1: 5,120$ in PBS) and precipitated urine protein $(0.001-4.56 \mathrm{mg} / \mathrm{ml})$ were determined by ic-ELISA, as described above. The nonmatrix effect was determined by the same value OD of the sample dilution and the OD of the PBS sample.

Calibration curves of the $\mathrm{A} \beta 1-42$ in urine and precipitated urine protein were obtained. Twelve concentrations of A $\beta 1-42(0-8,000 \mathrm{ng} / \mathrm{ml})$ were spiked into $1: 160$ urine in PBS and $0.456 \mathrm{mg} / \mathrm{ml}$ precipitated urine protein, and then, ic-ELISA was performed as described above. LODs were calculated as described above.

The correlation curves were obtained by comparing the concentration of spiked $A \beta 1-42$ samples and the detected concentration in the calibration curves.

\section{Results}

3.1. Development of ic-ELISA. To develop the ic-ELISA for the detection of $\mathrm{A} \beta 1-42$, alpaca antiserum was tested using indirect ELISA in the first step to determine the optimal concentration of coating antigen and the optimal dilution of antiserum. Six concentrations of $\mathrm{A} \beta 1-42$ in coating buffer were coated on the wells, and six serial dilution ratios from $1: 1,000$ to $1: 32,000$ of alpaca antiserum were investigated. The $1: 1,000$ dilution showed the highest binding sensitivity among all coating antigen concentrations (Table 1). Then, sensitivity of the indirect ELISA was tested with 15 concentrations of $\mathrm{A} \beta 1-42$. The half-maximal effective concentration $\left(\mathrm{EC}_{50}\right)$ of a $1: 1,000(\mathrm{v} / \mathrm{v})$ dilution of alpaca antiserum was $928.40 \mathrm{ng} / \mathrm{ml}$ as shown in Figure 1(a).

As the second step, the ic-ELISA was used to optimize the concentration of coating antigen (A $\beta 1-42)$. Three concentrations of $A \beta 1-42$, prepared at 2,000, 3,000, and $4,000 \mathrm{ng} / \mathrm{ml}$ in the coating buffer, were used as the coating antigen, and 


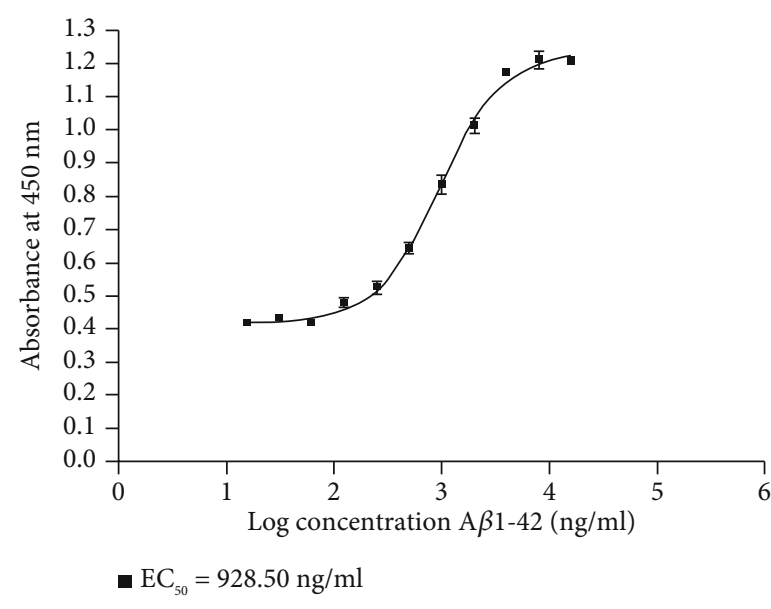

(a)

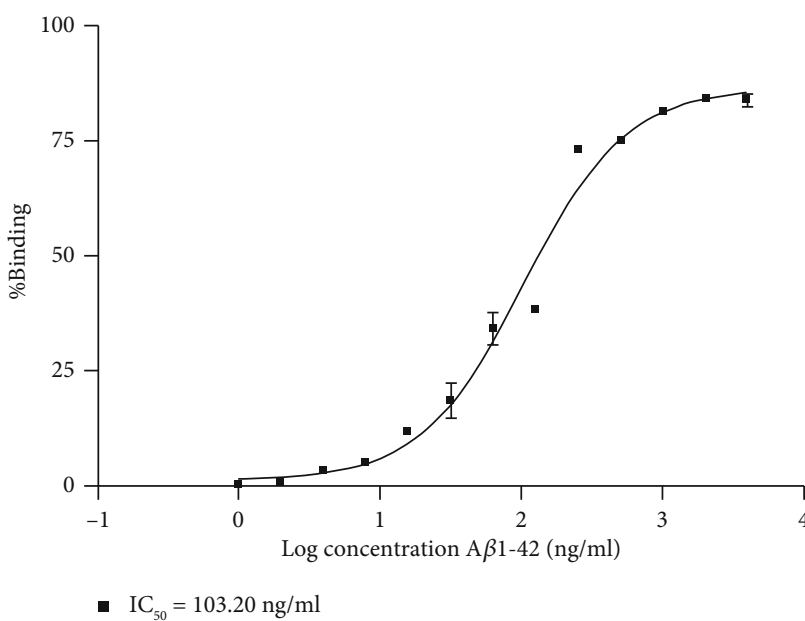

(c)

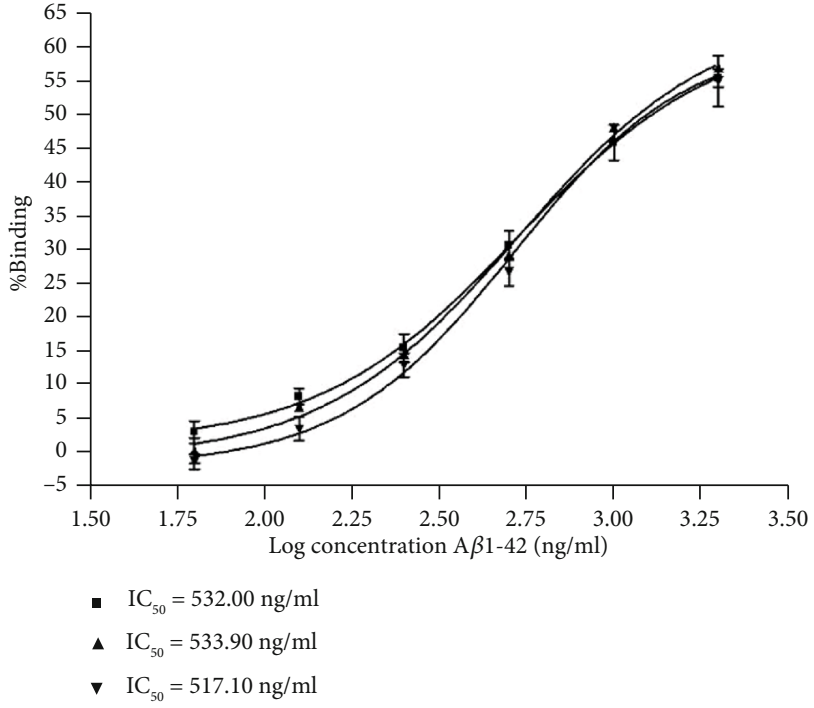

(b)

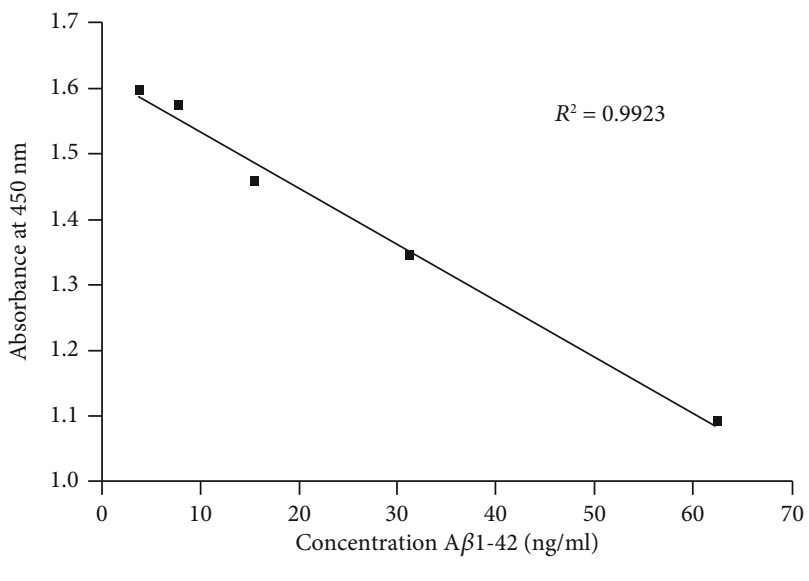

- $Y=-0.0086 \mathrm{X}+1.621$

Figure 1: Development of $\mathrm{A} \beta 1-42$ detection. (a) Indirect ELISA calibration curves for $\mathrm{A} \beta 1-42$ using 1:1,000 (v/v) dilution of alpaca antiserum. (b) Optimization of coating antigen using indirect competitive ELISA. The percent binding showed a competition percentage of 6 concentrations of competitive A $\beta 1-42(62,125,250,500,1,000$, and 2,000 ng/ml) to a $1: 1,000(\mathrm{v} / \mathrm{v})$ dilution of alpaca antiserum at 3 concentrations of coating antigen $(\boldsymbol{\nabla}=2,000, \boldsymbol{\Delta}=3,000$, and $\boldsymbol{\nabla}=4,000 \mathrm{ng} / \mathrm{ml}$ of A $\beta 1-42$ in coating buffer). (c) ic-competitive ELISA calibration curves for A $\beta 1-42$ using a 1:1000 (v/v) dilution of alpaca antiserum. The calibration curve was obtained using analyte standards prepared in PBS buffer. (d) ic-competitive ELISA calibration curves obtained by OD.

ic-ELISA was performed with a $1: 1,000(\mathrm{v} / \mathrm{v})$ dilution of alpaca antiserum, as described above. The coated concentration of 2,000 ng/ml A $\beta 1-42$ was selected since it showed the same half-maximal inhibitory concentration $\left(\mathrm{IC}_{50}\right)$ as the above concentrations (Figure 1(b)).

For the third step, the sensitivity of this method was determined. The $\mathrm{IC}_{50}$ of ic-ELISA was $103.20 \mathrm{ng} / \mathrm{ml}$ as shown in Figure 1(c). The LOD of this method was $0.39 \mathrm{ng} / 100 \mu \mathrm{l}$, calculated by the formula and OD calibration curve shown in Figure 1(d).

3.2. Cross-Reactivity of the Assay. The specificity of the developed ic-ELISA was assessed by measuring the cross-reactivity toward the same structural proteins as $A \beta 1-42$, using $A \beta 1$ 40 , and 8 synthesized $\mathrm{A} \beta$ peptides (GenScript, China) in the test (the sequence of peptides is shown in Table 2). The data within a range of 12 concentrations of the $\mathrm{A} \beta 1-42$ standard $(0-4,000 \mathrm{ng} / \mathrm{ml}$, twofold dilution in PBST) were used for the calculation of cross-reactivity. $A \beta 7-15, \mathrm{~A} \beta 14-21, \mathrm{~A} \beta 20$ 27, $A \beta 26-33, A \beta 32-39, A \beta 35-42$, and $A \beta 36-43$ showed no detectable cross-reactivity. However, A $\beta 1-8$ showed $69.40 \%$ and $A \beta 1-40$ showed $55.00 \%$ cross-reactivity as shown in Table 2, suggesting both can have some contribution to the measurement of the $\mathrm{A} \beta 1-42$ level with this method.

3.3. Matrix Effect on the A $\beta 1-42$ ic-ELISA. The developed icELISA was performed by using a $1: 1,000(\mathrm{v} / \mathrm{v})$ dilution of alpaca antiserum in 12 diluted samples $(1: 1-1: 5120$ in PBS) of pooled urine and 12 diluted samples of precipitated urine protein (urine protein $=0.001-4.56 \mathrm{mg} / \mathrm{ml}$ ) that were 
TABLE 2: Cross-reactivity of synthesized peptides and two beta amyloid proteins.

\begin{tabular}{lccc}
\hline Sample & Sequence & $\mathrm{IC}_{50}(\mathrm{ng} / \mathrm{ml})$ & \% cross-reaction \\
\hline $\mathrm{A} \beta 1-42$ & DAEFRHDSGYEVHHQKLVFFAEDVGSNKGAIGLMVGGVVIA & 103.20 & 100.00 \\
$\mathrm{~A} \beta 1-8$ & DAEFRHDS & 148.80 & 69.40 \\
$\mathrm{~A} \beta 1-40$ & DAEFRHDSGYEVHHQKLVFFAEDVGSNKGAIIGLMVGGVV & 187.70 & 55.00 \\
$\mathrm{~A} \beta 7-15$ & DSGYEVHHQ & $>4000$ & - \\
$\mathrm{A} \beta 14-21$ & HQKLVFFA & $>4000$ & - \\
$\mathrm{A} \beta 20-27$ & FAEDVGSN & $>4000$ & - \\
$\mathrm{A} \beta 26-33$ & SNKGAIIG & $>4000$ & - \\
$\mathrm{A} \beta 32-39$ & IGLMVGGV & $>4000$ & - \\
$\mathrm{A} \beta 35-42$ & MVGGVVIA & $>4000$ & - \\
$\mathrm{A} \beta 36-43$ & VGGVVIAT & $>4000$ & - \\
\hline
\end{tabular}

used as the matrix antigen of competition with coated $A \beta 1$ 42. The results had no matrix effect OD at $1: 160$ for the pooled urine, as shown in Figure 2(a), and $0.456 \mathrm{mg} / \mathrm{ml}$ for the urine protein, as shown in Figure 2(b). The calibration curve was obtained using analyte standard $\mathrm{A} \beta 1-42$ prepared in $1: 160$ diluted pool urine and $0.456 \mathrm{mg} / \mathrm{ml}$ precipitated urine protein. The results showed an $\mathrm{IC}_{50}=115.90 \mathrm{ng} / \mathrm{ml}$ for $1: 160$ pooled urine, as shown in Figure 3(a), and $579.00 \mathrm{ng} / \mathrm{ml}$ for precipitated urine protein, as shown in Figure 3(b). The LOD of this method was $16.83 \mathrm{ng} / \mathrm{ml}$ for the pooled urine sample and $139.60 \mathrm{ng} / \mathrm{ml}$ for the precipitated urine protein. The correlation of the detected and spiked concentrations of $A \beta 1-42$ in the samples by using the ic-ELISA calibration curve showed $R^{2}=0.9973$ for pooled urine (in the range $7.80-1000.00 \mathrm{ng} / \mathrm{ml} \mathrm{A} \beta 1-42$ ) as shown in Figure 3(c) and $R^{2}=0.9918$ for the precipitated urine protein (in the range $15.63-1000.00 \mathrm{ng} / \mathrm{ml} \mathrm{A} \beta 1-42$ ) as shown in Figure 3(d).

\section{Discussion}

We propose a new alternative method for the detection of $A \beta$ in human biological samples, an ic-ELISA for the detection of A $\beta 1-42$ in urine samples that we have developed. Most commercial ELISA test kits for $\mathrm{A} \beta$ in humans are developed based on sandwich-ELISA, which requires two antibodies for detection, and only a few commercial test kits can detect $\mathrm{A} \beta$ in urine. One advantage of our method is that it only requires one specific antibody and can be detected in urine samples. Another advantage of using a single antibody is reducing nonspecific bounding since other substances may affect each antibody. The commercial kits have a LOD between 4.73 and $1,000 \mathrm{pg} / \mathrm{ml}$, and their detection range is between 7.8 and $480,000 \mathrm{pg} / \mathrm{ml}$ for all $\mathrm{A} \beta$. A $\beta 1-42$ shows a lower concentration, where LOD is usually between 4.73 and $9.38 \mathrm{pg} / \mathrm{ml}$. Our method shows that the concentration of the LOD for $\mathrm{A} \beta 1-42$ is higher than the commercial kit at $3.90 \mathrm{ng} / \mathrm{ml}$ (390 pg/well), based on the levels of $\mathrm{A} \beta 1-42$ in human biological samples that are regularly monitored at relatively low levels: $750 \mathrm{pg} / \mathrm{ml}$ for CSF samples [28] and $17.65 \mathrm{pg} / \mathrm{ml}$ for serum samples [29]. So, we are not able to use the commercial methods to detect $\mathrm{A} \beta 1-42$ in these samples.
However, our method showed $69.4 \%$ and $55 \%$ crossreaction to the synthesized $A \beta 1-8$ and $A \beta 1-40$, respectively, as expected, since $A \beta 1-40$ has a sequence close to $A \beta 1-42$. Synthesized $A \beta 1-8$ also has a sequence present at the beginning of every $\mathrm{A} \beta$. The LOD of this method cannot detect $\mathrm{A} \beta 1-42$ in urine samples. However, due to the high crossreactivity, the method can be developed to detect total $\mathrm{A} \beta$ in urine and could be used to detect total $\mathrm{A} \beta$ in other biological samples.

In urine samples, the LOD was $16.83 \mathrm{ng} / \mathrm{ml}$ and $139.60 \mathrm{ng} / \mathrm{ml}$ for precipitated urine protein. Since urine contains inorganic ions $(\mathrm{K}+, \mathrm{Na}+, \mathrm{Cl}-$, and $\mathrm{Ca} 2+)$, organic molecules such as creatinine, urea, and uric acid, and more than 1,500 proteins, mainly extracellular, membranes, cell membranes, and cell debris, the higher LOD may come from the matrix in urine, which can interrupt the binding of antigens with antibodies used in the ELISA assays [30]. Another limitation of commercial ELISA kits is the price; most are expensive and cannot be routinely used for early detection in people. The yields of pAb from rodents are limited due to the size of the animal. In this study, the antibody was produced in an alpaca, whose blood can be collected in larger quantities, which allows our method to be developed at a lower cost.

A previous study reported that $A \beta$ is removed from circulation by the capillary beds of the kidneys, liver, and gastrointestinal tract, as well as through the skin and excreted in the urine [31]. According to studies from Takata et al., $\mathrm{A} \beta$ has a correlation with the clinical dementia rate (CDR) of people with $\mathrm{AD}$ and mild cognitive impairment (MCI), with an increasing value of $\mathrm{A} \beta$ in mild $\mathrm{AD}$ (CDR 0.5 to 1 ) and a decreasing value in more severe $\mathrm{AD}$ (CDR 2 to 3 ), since aggregated $\mathrm{A} \beta$ plaques might not be able to be eliminated via normal clearance routes in severe cases. The detection sensitivity of their method was $40 \mathrm{pg} / \mathrm{ml}$, which still cannot be quantified [21]. Since our new ic-ELISA method can detect this amount of $\mathrm{A} \beta$ in urine samples, it can be used as a preliminary assessment for $\mathrm{AD}$.

$\mathrm{A} \beta$ peptides are a normal component of human urine as identified in the study of Ghiso et al. [8], who conducted immunoprecipitation experiments with anti- $\mathrm{A} \beta$ antibodies followed by detection and identification by immunoblots and MALDI mass spectrometry. For $\mathrm{A} \beta$ levels in normal 


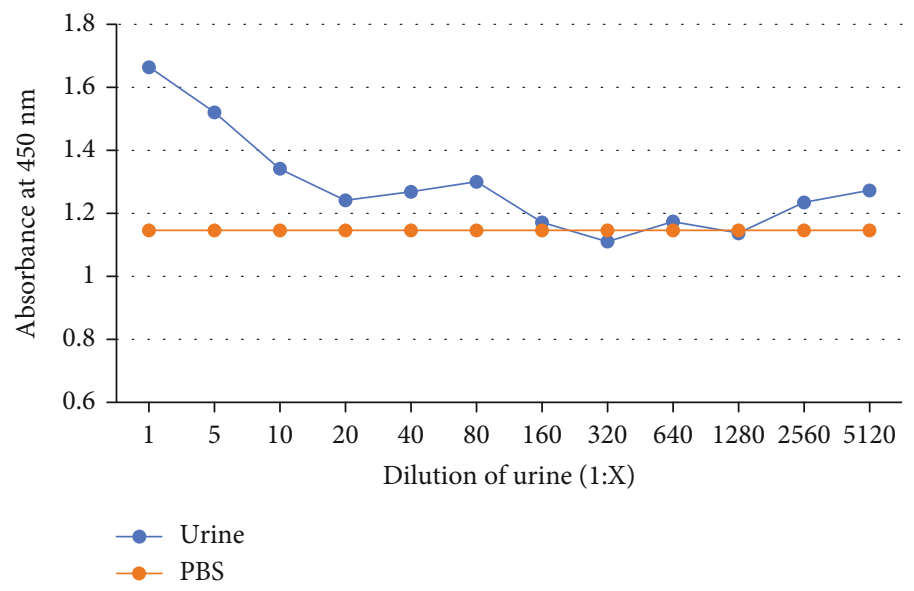

(a)

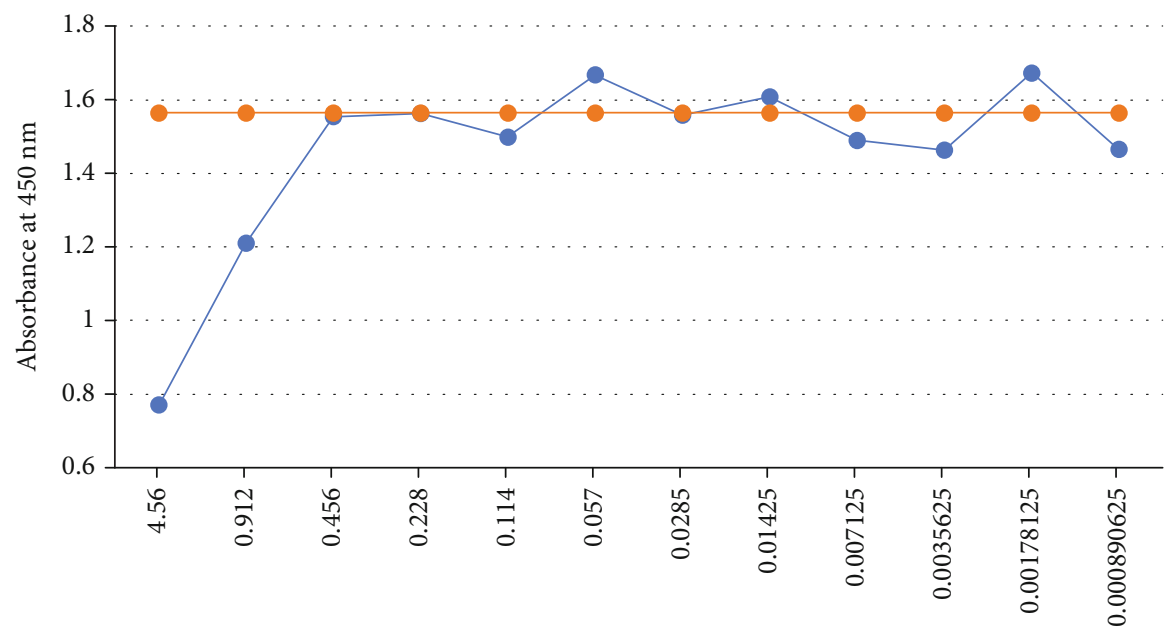

Concentration of precipitated urine protein $(\mathrm{mg} / \mathrm{ml})$

- Precipitated urine protein

$\rightarrow$ PBS

(b)

Figure 2: Observation of the urine matrix effect using ic-ELISA. (a) The curve was obtained using analyte 12 dilutions of pooled urine prepared in PBS buffer $(1: 1-1: 5120)$. (b) The curve was obtained using analyte 12 concentrations of precipitated urine protein prepared in PBS buffer $(0.001-4.56 \mathrm{mg} / \mathrm{ml})$.

donors (proteinuria $<5 \mathrm{mg} / \mathrm{dl}$ ), the excretion of soluble $\mathrm{A} \beta$ was calculated at $0.81 \pm 0.26 \mathrm{ng} / 5 \mathrm{mg}$ of urinary proteins $(13 \pm 4 \mathrm{ng} / 24 \mathrm{~h})$ [8]. Therefore, at this $\mathrm{A} \beta$ level, our method could measure the level of monomer $\mathrm{A} \beta$ in the urine. By applying urine sample preparation methods, such as precipitation techniques to increase the concentration of $A \beta$ in the urine sample, we can use $1 \mathrm{dl}$ of urine to prepare $5 \mathrm{mg}$ urine protein, which can reach approximately 1 ng of $\mathrm{A} \beta$ in normal donors. In addition, from the urine matrix tests, our method found an effect of the pooled urine at under $1: 160$ dilution (urine protein $<32.25 \mathrm{ng}$ in $100 \mu \mathrm{l}$ sample). This means that it is not possible to use this method to determine $\mathrm{A} \beta$ in urine samples without a sample pretreatment process. However, since precipitated urine protein has shown nonmatrix effect results at $0.456 \mathrm{mg} / \mathrm{ml}$ (urine protein = $0.05 \mathrm{mg}$ in $100 \mu \mathrm{l}$ sample) and unidentified inhibition results of 4.56 and $0.91 \mathrm{mg} / \mathrm{ml}$ (urine protein $=0.46$ and $0.09 \mathrm{mg}$ in
$100 \mu \mathrm{l}$ sample), it is possible to develop this method to detect amyloid in urine samples in combination with appropriate urine protein sample preparation.

The serum and CSF sample collection requires invasive methods and can be harmful to participants, while urine samples can be easily and not harmfully collected. The results can be corrected referencing the concentration of $\mathrm{A} \beta$ against urine creatinine and reported as microgram per milliliter urine or microgram per gram creatinine, as reported in several previous studies.

Most of the immunoassay methods were developed based on conventional antibodies and have some limitations, i.e., the lack of specificity of $\mathrm{pAb}$ and complicated production of $\mathrm{mAb}$ [32]. However, the production of a single-domain antibody (sdAb) from a phage display technique could provide more sensitivity, specificity, and stability of the antibody. In addition, a large number of antibodies can be produced by 


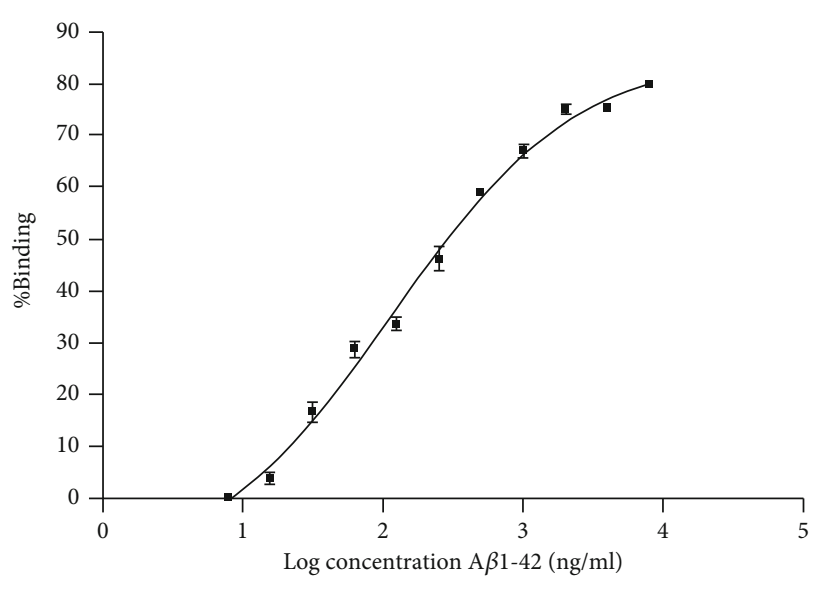

- $\mathrm{IC}_{50}=115.09 \mathrm{ng} / \mathrm{ml}$

(a)

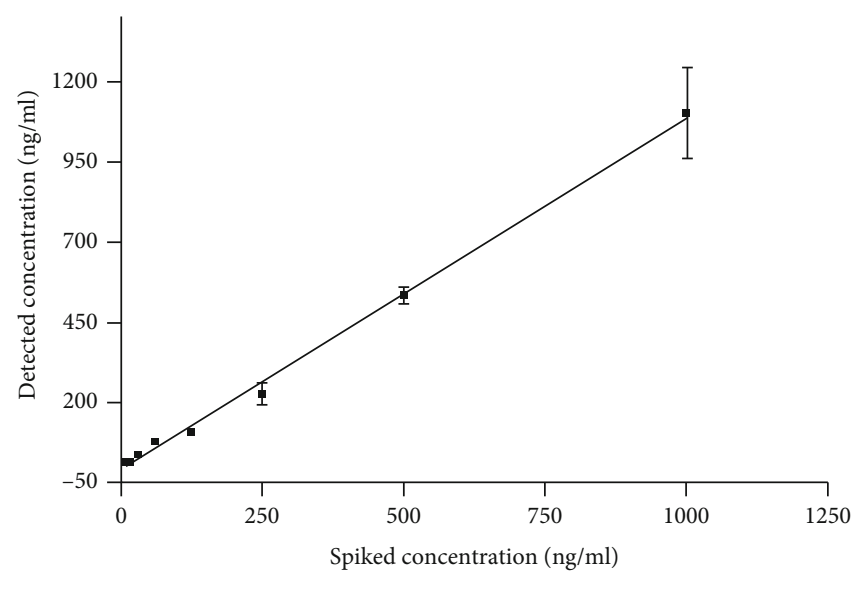

- $R^{2}=0.9973$

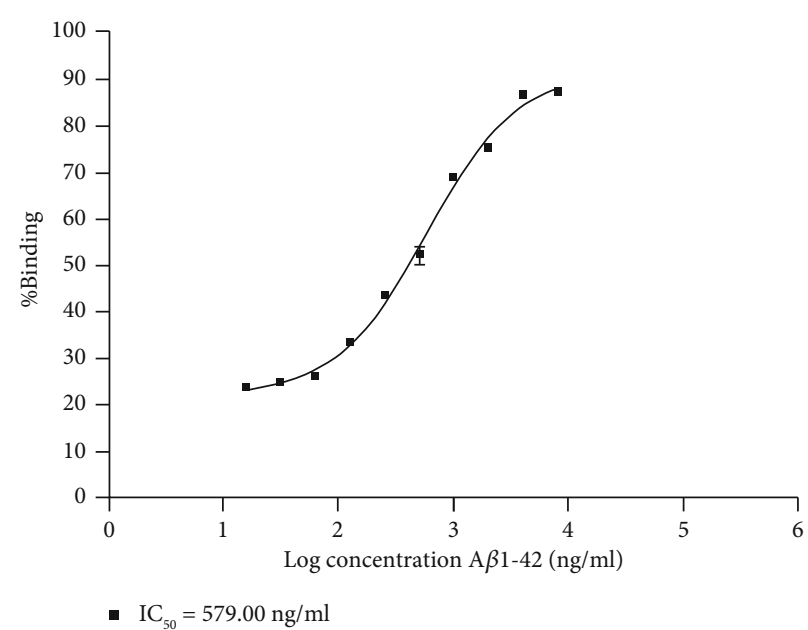

(b)

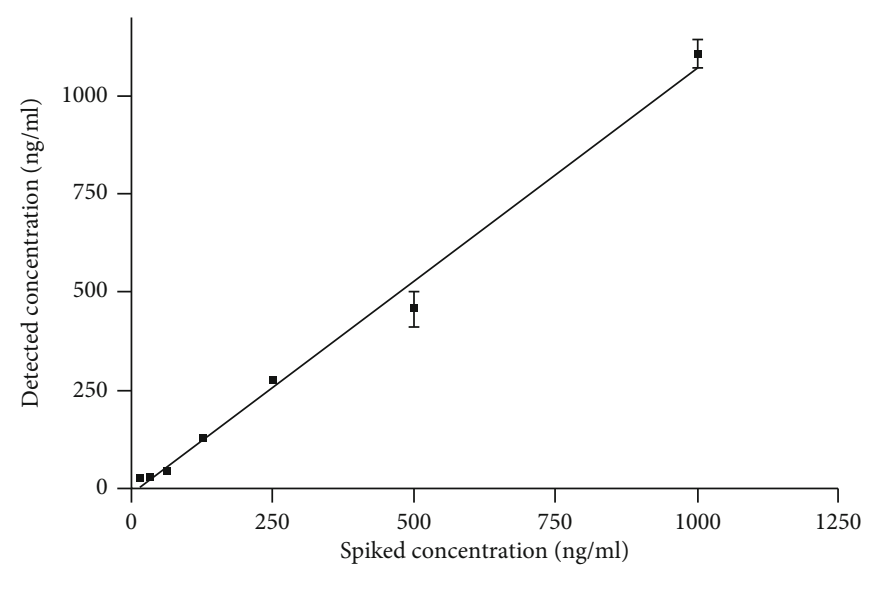

- $R^{2}=0.9918$

(c)

(d)

Figure 3: The ic-ELISA calibration curves for A $\beta 1-42$ using a $1: 1000$ (v/v) dilution of alpaca antiserum were obtained using analyte standards prepared in $0.456 \mathrm{mg} / \mathrm{ml}$ precipitated urine. (c) The correlation curve of the detected and spiked concentrations of $\mathrm{A} \beta 1-42$ in $1: 160$ diluted urine. (d) The correlation curve of the detected and spiked concentrations of A $\beta 1-42$ in $0.456 \mathrm{mg} / \mathrm{ml} \mathrm{precipitated} \mathrm{urine.}$

these methods [33]. An sdAb is an antibody fragment consisting of a single monomeric variable antibody domain, unlike a whole antibody, which can selectively bind to a very specific antigen. The sdAb could be produced from both conventional antibodies [34] and heavy chain antibodies from camelids [35].

In our study, an alpaca was immunized with $A \beta 1-42$ to produce antibodies. For our novel ic-ELISA for $\mathrm{A} \beta$, $\mathrm{pAb}$ was applied due to its convenience in the development of this method of examination, but $\mathrm{sd} A \mathrm{~b}$ for $\mathrm{A} \beta$ can be developed in the future.

\section{Conclusions}

The developed ic-ELISA indicated sensitivity for $A \beta 1-42$ and peptides having a similar structure. A $\beta 1-40$ showed $55 \%$ cross-reactivity, and the synthesized $\mathrm{A} \beta 1-8$, which consists of the same beginning sequence for all $\mathrm{A} \beta$, showed $69.4 \%$ cross-reactivity. In addition, the method showed no cross- reactivity to other synthesized $\mathrm{A} \beta$ peptides, which have the same sequence as $A \beta 1-42$ from different segments of the sequence. We can presume that the binding site of the antibody has the same sequence as A $\beta 1-8$ (DAEFRHD). The assay, as described in this study, has great potential to detect $\mathrm{A} \beta 1-42$ protein in cases of high-risk and early stages of $\mathrm{AD}$, with an easy and rapid method when applied to a urine sample. Moreover, this assay can be widely used at a low cost and applied to other types of biological samples.

\section{Data Availability}

All data were shown in the manuscript.

\section{Conflicts of Interest}

The authors declare no conflicts of interest. 


\section{Acknowledgments}

We gratefully acknowledge the support from the Research Institute for Health Science, Chiang Mai University, 50200, Thailand, and Guangdong Provincial Key Laboratory of Food Quality and Safety, College of Food Science, South China Agricultural University, Guangzhou, 510642, People's Republic of China.

\section{References}

[1] A. S. Schachter and K. L. Davis, "Alzheimer's disease," Dialogues in Clinical Neuroscience, vol. 2, no. 2, pp. 91-100, 2000.

[2] D. Yan, Y. Zhang, L. Liu, and H. Yan, "Pesticide exposure and risk of Alzheimer's disease: a systematic review and meta-analysis," Scientific Reports, vol. 6, no. 1, p. 3222, 2016.

[3] A. R. Armstrong, "What causes Alzheimer's disease," Folia Neuropathologica, vol. 3, no. 3, pp. 169-188, 2013.

[4] B. A. Yankner, L. K. Duffy, and D. A. Kirschner, "Neurotrophic and neurotoxic effects of amyloid beta protein: reversal by tachykinin neuropeptides," Science, vol. 250, no. 4978, pp. 279-282, 1990.

[5] E. Ghasemi, N. G. Azad, M. Tondar, P. Parirokh, and F. Aval, "Tracking the footprint of pesticides in Alzheimer's disease," Journal of Systems and Integrative Neuroscience, vol. 1, no. 1, pp. 14-19, 2015.

[6] S. Harald, F. Akio, T. Shinji, and O. Masayasu, "Making the final cut: pathogenic amyloid- $\beta$ peptide generation by $\gamma$-secretase," Cell Stress, vol. 2, no. 11, pp. 292-310, 2018.

[7] C. Haass and D. J. Selkoe, "Soluble protein oligomers in neurodegeneration: lessons from the Alzheimer's amyloid $\beta$-peptide," Nature Reviews. Molecular Cell Biology, vol. 8, no. 2, pp. 101-112, 2007.

[8] J. Ghiso, M. Calero, E. Matsubara et al., "Alzheimer's soluble amyloid $\beta$ is a normal component of human urine," FEBS Letters, vol. 408, no. 1, pp. 105-108, 1997.

[9] J. Hardy, K. Duff, K. G. Hardy, J. Perez-Tur, and M. Hutton, "Genetic dissection of Alzheimer's disease and related dementias: amyloid and its relationship to tau," Nature Neuroscience, vol. 1, no. 5, pp. 355-358, 1998.

[10] J. Ghiso and B. Frangione, "Amyloidosis and Alzheimer's disease," Advanced Drug Delivery Reviews, vol. 54, no. 12, pp. 1539-1551, 2002.

[11] T. Hartmann, S. C. Bieger, B. Brühl et al., "Distinct sites of intracellular production for Alzheimer's disease A $\beta 40 / 42$ amyloid peptides," Nature Medicine, vol. 3, no. 9, pp. 1016-1020, 1997.

[12] A. E. Roher, J. D. Lowenson, S. Clarke et al., "Beta-amyloid-(142 ) is a major component of cerebrovascular amyloid deposits: implications for the pathology of Alzheimer disease," Proceedings of the National Academy of Sciences, vol. 90, no. 22, pp. 10836-10840, 1993.

[13] T. Schirinzi, G. Di Lazzaro, G. M. Sancesario et al., "Levels of amyloid-beta-42 and CSF pressure are directly related in patients with Alzheimer's disease," Journal of Neural Transmission, vol. 124, no. 12, pp. 1621-1625, 2017.

[14] M. Lee, J. P. Guo, K. Kennedy, E. G. McGeer, and P. L. McGeer, "A method for diagnosing Alzheimer's disease based on salivary amyloid- $\beta$ protein 42 levels," Journal of Alzheimer's Disease, vol. 55, no. 3, pp. 1175-1182, 2017.
[15] M. N. Sabbagh, J. Shi, M. Lee et al., "Salivary beta amyloid protein levels are detectable and differentiate patients with Alzheimer's disease dementia from normal controls: preliminary findings," BMC Neurology, vol. 18, no. 1, p. 155, 2018.

[16] K. A. Johnson, N. C. Fox, R. A. Sperling, and W. E. Klunk, "Brain imaging in Alzheimer disease," Cold Spring Harbor Perspectives in Medicine, vol. 2, no. 4, article a006213, 2012.

[17] J. B. Toledo, L. M. Shaw, and J. Q. Trojanowski, "Plasma amyloid beta measurements - a desired but elusive Alzheimer's disease biomarker," Alzheimer's Research \& Therapy, vol. 5, no. 2, p. 8, 2013.

[18] S. D. Gan and K. R. Patel, "Enzyme immunoassay and enzyme-linked immunosorbent assay," Journal of Investigative Dermatology, vol. 133, no. 9, pp. 1-3, 2013.

[19] S. D. Schmidt, R. A. Nixon, and P. M. Mathews, "ELISA method for measurement of amyloid-beta levels," Methods in Molecular Biology, vol. 299, pp. 279-297, 2005.

[20] Biocompare, Excellent Technical Reproducibility - BetaAmyloid ELISA Kit, Biocompare, 2020, https://www .biocompare.com/Search-ELISA-Kits/?search=Amyloid\%2C +beta+42.

[21] M. Takata, M. Nakashima, T. Takehara et al., "Detection of amyloid $\beta$ protein in the urine of Alzheimer's disease patients and healthy individuals," Neuroscience Letters, vol. 435, no. 2, pp. 126-130, 2008.

[22] G. Y. Wiederschain, "The ELISA guidebook," Biochemistry (Moscow), vol. 74, no. 9, pp. 1058-1058, 2009.

[23] J. R. Crowther, "ELISA. Theory and practice," Methods in Molecular Biology, vol. 42, pp. 1-218, 1995.

[24] S. D. Schmidt, M. J. Mazzella, R. A. Nixon, and P. M. Mathews, "A $\beta$ measurement by enzyme-linked immunosorbent assay," Methods in Molecular Biology, vol. 849, pp. 507-527, 2012.

[25] K. Linnet and M. Kondratovich, "Partly nonparametric approach for determining the limit of detection," Clinical Chemistry, vol. 50, no. 4, pp. 732-740, 2004.

[26] J. Ruprich and V. Ostrý, "Immunochemical methods in health risk assessment: cross reactivity of antibodies against mycotoxin deoxynivalenol with deoxynivalenol-3-glucoside," Central European Journal of Public Health, vol. 16, no. 1, pp. 3437, 2008.

[27] S. Englard and S. Seifter, "[22] precipitation techniques," Methods in Enzymology, vol. 182, pp. 285-300, 1990.

[28] H. M. Brothers, M. L. Gosztyla, and S. R. Robinson, "The physiological roles of amyloid- $\beta$ peptide hint at new ways to treat Alzheimer's disease," Frontiers in Aging Neuroscience, vol. 10, p. 118, 2018.

[29] C. Zecca, R. Tortelli, F. Panza et al., "Plasma $\beta$-amyloid1-42 reference values in cognitively normal subjects," Journal of the Neurological Sciences, vol. 391, pp. 120-126, 2018.

[30] D. Chatziharalambous, V. Lygirou, A. Latosinska et al., "Analytical performance of ELISA assays in urine: one more bottleneck towards biomarker validation and clinical implementation," PLoS One, vol. 11, no. 2, article e0149471, 2016.

[31] Y. Xiang, X. L. Bu, Y. H. Liu et al., "Physiological amyloid-beta clearance in the periphery and its therapeutic potential for Alzheimer's disease," Acta Neuropathologica, vol. 130, no. 4, pp. 487-499, 2015.

[32] N. S. Lipman, L. R. Jackson, L. J. Trudel, and F. Weis-Garcia, "Monoclonal versus polyclonal antibodies: distinguishing characteristics, applications, and information resources," ILAR Journal, vol. 46, no. 3, pp. 258-268, 2005. 
[33] T. De Meyer, S. Muyldermans, and A. Depicker, "Nanobodybased products as research and diagnostic tools," Trends in Biotechnology, vol. 32, no. 5, pp. 263-270, 2014.

[34] L. J. Holt, C. Herring, L. S. Jespers, B. P. Woolven, and I. M. Tomlinson, "Domain antibodies: proteins for therapy," Trends in Biotechnology, vol. 21, no. 11, pp. 484-490, 2003.

[35] E. Pardon, T. Laeremans, S. Triest et al., "A general protocol for the generation of nanobodies for structural biology," Nature Protocols, vol. 9, no. 3, pp. 674-693, 2014. 